\section{Structure of Quercus}

suber forests in

\section{Chefchaouen basin}

\section{(NE. Morocco).}

\section{Implications on}

\section{management at a \\ landscape scale}

\author{
Antonio Pastor-López', \\ Lahcen Taiqui' \\ Hassan Bouziane ${ }^{2}$, \\ Hassan Riadi', \\ Joaquín Martín Martín'
}

\begin{abstract}
An structural characterization of the Quercus suber forests and its derived formations is defined for the Chefchaouen basin in NE. Moroceo. Four structural types identified from aerial photographs interpretation were related to sile conditions defined by three variables (lithology, slope and aspect) by means of a GIS. Five patterns resulted from the cluster analysis of the percentages of the area -per site conditioncovered by each structural type. Forests on numidian sandstones lithologies, oriented to the east or north, and slopes from $15 \%$ to $50 \%$ were the most susceptible to complete deforestation. On the detailed description of 15 stands the deforestation process of the cork oak (Quercus suber) forests is discussed. Suggestion for more sustainable management practices were stated after comparation with other similar systems.
\end{abstract}

\section{RESUMEN}

Los bosques de Quercus suber y sus formaciones derivadas tras perturbación fucron caracterizados para la Cuenca de Chefchaouen en el NE. de Marruecos. Cuatro tipos estructurales, identificados por fotointerpretación, se relacionaron con las condiciones ambientales, definidas mediante un Sistema de Información Geográfica. Cinco patrones resultaron del analisis cluster de los porcentajes del área -por condición ambiental- cubiertos por cala tipo estructural. Los bosques sobre litología de areniscas numidicas, expuestos al este o norte y con pendientes del 15 al $50 \%$ son los más susceptibles de sufrir una deforestación completa.

' Dpto. Ecología, Fac. Ciencias, Univ. Alicante, Ap.C.99, 03080 Alicante, Spain. "Dept. Biologie, Fac. Sciences, Univ. A. Essaâdi, B.P.2121, 93000 Tétouan, Moroceco.
En base a una descripción detallada de 15 parcelas, se procede a una discusión sobre los procesos de deforestación de los alcornocales (Quercus suber). Trás una comparación con otros sistemas similares, se proponen varias sugerencias de manejo sostenible.

\section{INTRODUCTION}

The Mediterranean Sea separates its Basin in two sectors that although rather similar from a climatic point of view present important differences from a more integrative perspective. The socioeconomic characteristics and the interaction between man and its biotic and abiotic environment are markedly distinct. This contrasting reality is the result of different land uses by man under a relatively homogeneous environmental framework. Different authors (DI CASTRI, 1979; LE HOUEROU, 1979) point out that despite their proximity in distance their main environmental concerns on a short and middle term perspective are not the same. On the other hand the need for sustainable solutions to the use or exploitation of natural resources is a shared concern. This new and reinforced goal (LUBCHENKO et al., 1991) has implications not just on the preservation of the wealth of each one of the states but on their interactions. The pronounced differences on the socioeconomic conditions between the South and the North impede a sustainable development in all mediterranean countries. The reason being the need to maintain and promote to its maximum, systems that are sociologically, economically and ecologically sound. From this perspective the promotion of economic and technical support from the economically stronger countries of the northern mediterranean must give priority to the implementation of politics directed to reach these sustainable systems in every country.

In the Rif region of Morocco the risk of deforestation is one of the main concerns related to lost of sustainability of the rural landscapes. Erosion and lost of soil productivity can be observed in important areas. A demographic boom in combination with a marked dependence on wood, as an energy source, threatens the sustainability of once extensive cork oak (Quercus suber) forested areas.

The introduction of the spanish forest exploitation philosophy by the Spanish Protectorate initiated a process that has led to a progressive reduction in the extension of closed canopy forests. The persistence of the exploitation of charcoal to fulfil the requirements from the larger cities in the vicinity, like Tetouan (BOUKIL, 1989), and wood gathering by the local people are not sustainable at the actual rates of extraction.

In the Rif region, Quercus suber forests are extensive and represent the dominant forest type in comparison with those from other species. For the Mediterranean countries, Morocco includes 347.000 ha. approximately $15.4 \%$ of the total. From an internal perspective the cork oak forest in the Rif represent $30.5 \%$ (BENABID, 1989) of the 
national ones. Important both for cork and wood production its management requires a deeper knowledge on its productivity and its response to the dominant exploitation or utilization systems. This is a basic step to maximize its productivity reducing the risk of regression. From a functional point of view the persistence of the extension of these forests and the appropriate management of their structure is basic to maintain the richness of these systems from a biodiversity as well as a cultural perspective.

This paper characterizes the structure for cork oak forests and derived communities after exploitation in the Chefchaouen Basin as a representation of this type of systems in the mountains of the western Rif. This description focuses on two main points: First, the definition of the trends or tendencies in the deforestation of these stands, in the search for an indication of the type of stands that are more susceptible to degradation. Second, the estimation of the amount of biomass as a fundamental descriptor in the management of these forests.

This contribution should be considered as a preliminary approach to the analysis of Chefchaouen basin in order to define a hierarchy of subjects to address more deeply in future studies. The definition of a sustainable system managing the use of cork oak forest in this area can not be produced now. The discussion centers on evaluating the consequences of the actual trends of exploitation, and on the need for specific data that will allow to fulfil this goal. These topics are analyzed in the search for a landscape perspective, for it is the scale we believe that best will allow the definition of the mentioned sustainable systems.

\section{STUDY AREA.}

The study area is included in the upper part of the Laou Basin, located in the Eastern sector of the Tingitane Peninsula, in the Northern part of Morocco. With an extension of $442 \mathrm{Km}^{2}$ belongs to the provinces of Chefchaouen and Tetouan. Geomorphologically describes an elongated basin which main axis runs from $\mathrm{N}$ to $\mathrm{S}$. It is flanked by calcareous ranges in the eastern side that include the highest elevations $(2159 \mathrm{~m}$.) at Djbel Lakraâ and by siliceous materials in the western sectors. Numerous streams run from both slopes to the lowlands located at altitudes of about 300 meters. The climatic conditions are predominantly mediterranean warm subhumid (BENABID, 1982). The values for the main descriptors for the existing thermopluviometric stations are included in Table 1.

All the riparian systems flow out of the basin in the vicinity of the village of Oued Lau. Through the steep and narrow Tamrabet canyon, the Laou river heads northeastward to the Mediterranean Sea just $30 \mathrm{~km}$. away. The Ali Thelat dam built in 1931 retains the water before this exit canyon and is an evident proof of the deforestation and erosion for it is almost completely silted. This accumulation of fine materials allows that during most of the year the new deposits are cultivated for corn and other vegetables crops, being used as rangelands during the remaining time. Most of the western sector of the basin with a wide bajada of relatively soft slopes include the larger extension of Quercus suber forests. To the north in the vicinity of the village of Rinfine, extensive areas of land mainly dedicated to wheat and barley production reflect the consequences of the degradation of the cork oak and other thermomediterranean forests by intense human pressure. To the south in the steeper and undulated terrains between the city of Chefchaouen and the village of Bab Taza different levels of degradation of the cork oak forests indicate the type of practices that are causing the regression. As in most of the Rif, the kif (Cannabis sativa) is produced in cleared areas inside and outside the forests playing a fundamental role in the socioeconomic activity in the area. The degradation thresholds for these forests are essential in the definition of sustainable management strategies.

\begin{tabular}{|c|c|c|c|c|c|c|}
\hline \multicolumn{7}{|c|}{$\begin{array}{l}\text { CIIMATIC STATIONS OI THHE CHEICHAOULN } \\
\text { l ocation and main descriptors }\end{array}$} \\
\hline Name & $\begin{array}{l}\text { Lat } \\
\mathrm{N}\end{array}$ & $\begin{array}{l}\text { Long } \\
\text { W.Gr. }\end{array}$ & $\begin{array}{l}\text { Alt } \\
(\mathrm{m})\end{array}$ & $\begin{array}{c}P \\
(\mathrm{~mm})\end{array}$ & $\begin{array}{l}M \\
(\mathrm{C})\end{array}$ & $\begin{array}{c}\mathrm{m} \\
(\mathrm{C})\end{array}$ \\
\hline $\begin{array}{l}\text { Ali } \\
\text { Thelat }\end{array}$ & $3515^{\prime}$ & $518^{\prime}$ & 250 & 681 & 31.9 & 6.1 \\
\hline $\begin{array}{l}\text { Bab } \\
\text { Taza }\end{array}$ & $3503^{\prime}$ & $512^{\prime}$ & 880 & 1482 & 32.5 & 2.5 \\
\hline $\begin{array}{c}\text { Chefchaouen } \\
\text { CT }\end{array}$ & 3511 ' & $519^{\prime}$ & 280 & 1005 & 33.5 & 5.5 \\
\hline $\begin{array}{c}\text { Chefchaouen } \\
\text { Ville }\end{array}$ & $3510^{\prime}$ & $516^{\prime}$ & 630 & 949 & 33.1 & 5.9 \\
\hline
\end{tabular}

Table 1.- Characteristics of meteorological stations located in the Chefchaouen basin: Lat. $\mathrm{N}$. north latitude; Long. W. $\mathrm{Gr}=$ longitude west of Greenwich; Alt $=$ Altitude over sea level; $P=$ average annual precipitation; $M=$ average maximum temperature; $m=$ average minimum temperature. 


\section{METHODOLOGY}

The information gathered for the cork oak forests is the result of two basic processes. First, the cartographic representation of the structural types of these forests that can be defined from a qualitative description of the whole basin. Second, the dendrometric characterization of different stands representative of the dominant structural types. This information was processed to determine the range of biomass accumulated as an useful indicator for comparison purposes with other stands of this and other species better known.

Four types of cork oak forest were defined: Q1 (forest with an open tree canopy where many crown contact each other, and with a high shrub cover); Q2 (forest with an open tree canopy where most crown are isolated, with a closed and high shrub understory); Q3 (tall shrubs with some openings); Q4 (short and scattered shrubs). Each structural type was identified from the analysis of aerial photographs (E 1:20000; 1986) for the whole basin. The areas covered by each type were delimited and represented by stereoscopic interpretation on topographic maps (E 1:50000; Division de la Cartographie - M.A.R.A. Rabat). From these topo maps they were digitized and incorporated to the G.I.S. IDRISI Windows 1.0 (1995).

From the digitalisation of hypsography data a Digital Elevation Model was obtained for the production of slope and aspect maps. The 10 slope classes considered match in part with the US Soil Survey slope classification classes, allowing their comparison. The slope intervals limits that match between both classification are $3 \%$, $20 \%$ and $50 \%$. The aspect categories defined were N, S, E, $W$ and leveled. From geological maps (Division de la Geologie - M.E.M. Rabat), 6 lithological classes were defined: lithol (coluvial detritic materials: glacis); litho2 (quaternary); litho3 (cretaceous marls: Tanger and Melloussa units); litho4 (flyschs of Beni Ider unit); litho5 (flyschs of Tizirène unit); litho6 (numidians sandstones). The combination via GIS of these three variables showed the heterogeneity for the main physical abiotic conditions.

In order to define the relation between the resulting combinations of environmental conditions and the cork oak forest degradation, the area covered by each one of the above mentioned structural types was determined for every environment. We assumed that the perturbations on the forests would affect more severely those environments more susceptible to perturbation or with a lower regeneration capacity as well as those that had suffered a higher pressure. Therefore those environments would have a lower percentage of their area covered by cork oak forest with a better structure and more derived shrublands. To make easier the comparation of the different environments we searched for similar patterns in the percentages of areas covered by each one of the four structural types considered. This step was completed by using a cluster analysis PKM of BMDP (DIXON, 1983) which establishes a certain number of homogeneous groups of cases. The resulting clusters were used as a synthetic descriptor of the structural patterns present and allowed the stablishment of similarities or trends in the consequences of the perturbation regime.

On the other hand, a series of stands, selected as representative of the dominant structural types in the basin, were more precisely quantified. Stem perimeters at 1.3 meters in height were determined for all the trees in plots 1000 square meters in area. For the shrub layer description, both in stands with and without Quercus suber tree canopy, line transects were completed. Each plot was sampled with five 20 meters parallel line transects separated 10 meters from each other. Cover values and number of contacts in 100 meters were measured for all the vegetation and for those species that can be used as a fuel source by the local people.

Biomass was considered the most appropriate structural descriptor. In this study, it iwas directly related to the potential amount of wood, available as an energy source.

The estimation of biomass for Quercus suber was the main goal, for it is much more susceptible to deforestation. Once the tree canopy is removed, degradation is accelerated. Characterizations for cork oak stands are commonly based on cork productivity and quality. More integrated analysis of aboveground productivity are scarce, but they are basic for management purposes. To determine the values of dry weight for different tree fractions we applied the allometric equations developed by CARITAT et al. (1992) to the d.b.h. determined for every tree in the plot. The biomass for the different plots was estimated and used as an indication of the order of magnitude that would be expected at a landscape scale.

From the equations to determine dry weight obtained by CARITAT et al. (1992), we used those for the site named Fitor. Between the two available set of equations one for Fitor and another for St. Hilari we choosed the former one for the range of d.b.h. includes the values obtained for the trees measured by us. The equations for St. Hilari were developed for larger trees and therefore the use of those equations in our sample would overestimate the dry weights. Basal areas were also more similar to those observed in our plots. Precipitation was higher in the Chefchaouen sites. Fitor and St. Hilari received a mean annual precipitation of 659 and $858 \mathrm{~mm}$. Fitor had more thermophilous conditions with a mean annual temperature of 15.1 degrees Celsius, what is more similar to the Chefchaouen basin. 
The equations used for dry weight determination used were:

$\begin{array}{llc}\log \text { TADW } & =2.7615 * \log \text { d.b.h. }-1.3934 & \left(\mathrm{R}^{2}=0.9766\right) \\ \log \mathrm{BDW}=1.1809 * \log \text { d.b.h. }+0.3905 & \left(\mathrm{R}^{2}=0.5641\right) \\ \log \text { PBDW }=4.7367 * \log \text { d.b.h. }-4.6567 & \left(\mathrm{R}^{2}=0.8007\right) \\ \log \mathrm{SBDW}=0.6280 * \log \text { d.b.h. }+0.9248 & \left(\mathrm{R}^{2}=0.4050\right) \\ \log \text { BKDW }=1.2226 * \log \text { d.b.h. }+0.0581 & \left(\mathrm{R}^{2}=0.8390\right) \\ \log \mathrm{LDW} & =0.6274 * \log \text { d.b.h. }-0.4784 & \left(\mathrm{R}^{2}=0.3987\right)\end{array}$

TADW = total aboveground dry weight; BDW $=$ bole dry weight; $\mathrm{PBDW}=$ primary branches dry weight; SBDW $=$ secondary branches dry weight; $\mathrm{BKDW}=$ bark dry weight (includes the bark for the whole tree); LDW = Leaves dry weight. All dry weights are expressed in $\mathrm{Kg}$. and all d.b.h. are in $\mathrm{cm}$.

\section{RESULTS}

\section{Characteristics of The Chefchaouen basin at a lands- cape scale:}

For the Chefchaouen basin several landscape units could be initialy defined from a visual inspection. In order of magnitude or area covered forests by Quercus suber and derived formations after perturbation or management represents $28.4 \%$ whilst cerealistic fields covers $33 \%$ of the total surface basin.

Deforestation is one the main causes that generates regressive processes as increased erosion and lost of soil structure and productivity. Although the peak of erosion and soil degradation occurs at faster rates in other landscape units (as the cerealistic fields in the northern sector of the basin) the main concern in the search for sustainable systems in this area must focus on sustainable ways of managing the Quercus suber forests. To describe the different landscape elements present, an structural characterization was considered the best way. A classification of the vegetation units was postponed. Biomass was the descriptor that better could connect the theoretical description of these stands to the demands for charcoal, fuel wood or fodder, resources extracted from these systems, driving therefore their progressive deterioration.

Describing this landscape unit, two were our main concerns. First, how to relate the structural types observed to specific perturbation agents and/or regimes? Second, would the resulting structure be an effect of the type of perturbation or of the topographic and physicochemical characteristics of the lands covered by the forest?. The search for information on the perturbation types and regimes gave such a variety of possibilities that we considered there was not enough information to proceed in this direction. We focused our interest in the second question.
The availability of a GIS and the existence of a relatively recent 1986 flight allowed a wide characterization of the different habitats where Quercus suber appeared or had appeared in the basin. We considered Quercus suber formations all those that evidence its actual presence or previous existence, either if they were physical (dead stumps) or biologicaly related (plant species characteristics of cork oak vegetation communities). Due to the lack of easy to obtain information (basic or thematic cartography) it was decided that a first approach to define the heterogeneity of the habitats could be done by combinig the information on three main descriptors: lithology, slope and aspect. The fact that the basin -as well as an important part of the Rif- had subhumid mediterranean climate conditions led us to believe that the weight of the climatic variables would not be as important as in semiarid or arid mediterranean climates. Therefore other edaphic and water-economy related variables would have higher importance than in semiarid conditions where precipitation and temperature normaly outweight the former variables.

Based on this approach the analysis of the structural characteristics for cork oak at a landscape scale was initiated by generating with GIS the coverages for those descriptors and using the classes mentioned in the methodology. From the analysis and quantification of the area resulting of the combination of each coverage with that of cork oak formations we obtained the following results. The total area covered by cork oak formations was of $1255 \mathrm{I}$ ha. In relation to the four physiognomic or structural types considered; Q1 represented $53.1 \%$ of the cork oak formations area, being therefore dominant. The other three types: Q2, Q3 and Q4 contribute with a 34.3\%, 10.3\% and 2.3\% repesctively.

The lithological classes defined showed different representation. The tendencies for the percentage of surface covered by each one of the structural types is compiled in table 2.1. Three groups could be defined with similar extension lithol and litho3 as the most abundant; litho2 and litho6 as the intermediate and litho4 and litho5 as the least represented. The percentage for each structural type showed important differences for litho6 respect to the other lithologies.

The slope intervals analyzed showed, as can be seen in table. 2.2 a dominance of areas with slope 3 and slope 4 ( $7 \%$ to $12 \%$ and $12 \%$ to $15 \%$ respectively). The least represented classes werf in both ends of the spectrum. Around $81 \%$ of the cork oak forest formations considered appeared in terrain with slopes between $7 \%$ and $28 \%$. Slope 3 has the maximum percentage in formations that retained a tree canopy (Q1 and Q2 together). Q1 structural type reached a $92 \%$ for the steepest slope class. 


\begin{tabular}{|c|c|c|c|c|c|c|}
\hline \multicolumn{7}{|c|}{$\begin{array}{c}\text { TOTAL AREA AND PERCENTAGES COVERED BY QUERCUS SUBER } \\
\text { OR DERIVED FORMATIONS FOR DIFFERENT LITHOLOGIES }\end{array}$} \\
\hline LITHOT & $\begin{array}{l}\text { TOTSUR } \\
\mathbf{H a}\end{array}$ & $\begin{array}{l}\text { Q1 } \\
\%\end{array}$ & $\begin{array}{l}\text { Q2 } \\
\%\end{array}$ & $\begin{array}{l}\text { Q3 } \\
\%\end{array}$ & $\begin{array}{l}\text { Q4 } \\
\%\end{array}$ & $\begin{array}{c}\text { TOT } \\
\%\end{array}$ \\
\hline lithol & 4178.65 & 54.45 & 38.27 & 4.48 & 2.80 & 33.29 \\
\hline litho2 & 1549.90 & 59.08 & 38.39 & 0.56 & 1.97 & 12.35 \\
\hline litho3 & 3619.80 & 55.04 & 33.02 & 8.70 & 3.24 & 28.84 \\
\hline litho4 & 1006.08 & 59.69 & 28.72 & 10.34 & 1.25 & 8.02 \\
\hline litho5 & 684.06 & 56.98 & 26.96 & 15.99 & 0.08 & 5.45 \\
\hline litho6 & 1512.40 & 32.36 & 29.49 & 37.40 & 0.74 & 12.05 \\
\hline total & 12550.89 & 53.09 & 34.33 & 10.28 & 2.30 & 100.00 \\
\hline
\end{tabular}

Table 2.1.- Percentages of area covered by the four structural types present. lithol = coluvial detritic materials (glacis); litho2 = quaternary; litho $3=$ cretaceous marls; 1 itho4 $=$ flyschs of BI; litho5 = flyschs of $T \%$; litho $6=$ numidians sandstones. (TOTSUR $=$ total surface); (TOT $\%=$ percentage that represent every lithological type from all the area covered by cork oak related vegetation).

\begin{tabular}{|c|c|c|c|c|c|c|}
\hline \multicolumn{7}{|c|}{$\begin{array}{l}\text { TOTAL AREA AND PERCENTAGES COVERED BY QUERCUS SUBER AND } \\
\text { DERIVED FORMATIONS FOR DIFFERENT SLOPE CONDITIONS }\end{array}$} \\
\hline SLOPE & $\begin{array}{l}\text { TOTSUR } \\
\mathbf{H a}\end{array}$ & $\begin{array}{l}\text { Q1 } \\
\%\end{array}$ & $\begin{array}{l}\mathrm{Q} 2 \\
\%\end{array}$ & $\begin{array}{l}\text { Q3 } \\
\%\end{array}$ & $\begin{array}{l}\text { Q4 } \\
\%\end{array}$ & $\begin{array}{c}\text { TOT } \\
\%\end{array}$ \\
\hline slo1 & 445.34 & 59.12 & 35.73 & 4.46 & 0.69 & 3.55 \\
\hline slo2 & 936.19 & 55,99 & 37.60 & 3.47 & 2.95 & 7.46 \\
\hline slo3 & 4158.23 & 53.71 & 42.41 & 1.75 & 2.12 & 33.13 \\
\hline slo4 & 2310.42 & 56.51 & 34.49 & 5.92 & 3.08 & 18.41 \\
\hline slo5 & 1423.17 & 53.79 & 31.41 & 11.81 & 2.98 & 11.34 \\
\hline slo6 & 665.89 & 43.79 & 30.51 & 22.79 & 2.90 & 5.31 \\
\hline slo7 & 1435.04 & 48.60 & 23.69 & 26.76 & 0.95 & 11.43 \\
\hline slo8 & 714.37 & 47.08 & 22.89 & 29.14 & 0.89 & 5.69 \\
\hline $\sin 9$ & 422.85 & 49.48 & 19.59 & 26.87 & 4.06 & 3.37 \\
\hline slo10 & 39.40 & 92.01 & 2.28 & 5.71 & 0.00 & 0.31 \\
\hline total & 12550.89 & 53.09 & 34.33 & 10.28 & 2.30 & 100.00 \\
\hline
\end{tabular}

Table 2.2.- Percentages of area covered by the four structural types of cork oak vegetarion formations for each of the ten slope classes present. The interval upper limits for each slope class expressed in percentage are: $s 11(3 \%)$; slo2(7\%); slo $3(12 \%) ; \operatorname{slo} 4(15 \%)$; slo5(18\%); slo6(20\%): $\sin 8(35 \%) ; \operatorname{slo} 9(50 \%)$ and siolo(over $50 \%)$

TOTAL AREA AND PERCENTAGES COVERED BY QUERCUS SUBER OR DERIVED FORMATIONS BY ASPECT CLASSES

\begin{tabular}{|c|c|c|c|c|c|c|}
\hline ASPECT & $\begin{array}{c}\text { TOTSUR } \\
\mathbf{H a}\end{array}$ & $\begin{array}{l}\text { Q1 } \\
\%\end{array}$ & $\begin{array}{l}\text { Q2 } \\
\%\end{array}$ & $\begin{array}{l}\text { Q3 } \\
\%\end{array}$ & $\begin{array}{l}\text { Q4 } \\
\%\end{array}$ & $\begin{array}{c}\text { TOT } \\
\%\end{array}$ \\
\hline $\mathbf{N}$ & 3192.82 & 54.16 & 34.61 & 9.56 & 1.67 & 25.44 \\
\hline E & 6387.79 & 47.58 & 36.37 & 12.80 & 3.26 & 50.90 \\
\hline S & 1492.34 & 64.90 & 25.69 & 8.48 & 0.92 & 11.89 \\
\hline $\mathrm{W}$ & 1464.90 & 62.34 & 33.97 & 2.74 & 0.95 & 11.67 \\
\hline leveled & 13.04 & 100.00 & 0.00 & 0.00 & 0.00 & 0.10 \\
\hline total & 12550.89 & 53.09 & 34.33 & 10.28 & 2.30 & 100.00 \\
\hline
\end{tabular}

Table 2.3.- Percentages of area covered by the four structural types of cork oak vegetation formations for each of the five aspect classes considered 
When considering aspect, summarized in table 2.3 half of the formations are oriented to the East, a quarter to the North and the other two share a similar area. Leveled terrain represents just a $0.1 \%$. When considering the structural type of cork oak formations Q1 is dominant in all aspects.

\section{Relation between cork oak formations structure and combined habitat characteristics:}

Several assumptions were made to analyse the trends in the regression of the cork oak formations: First, the minimum potencial extension of Q1 type could be estimated from the summatory of all the structural types actualy present. Second, by analyzing the area that appears now with a structural type Q1, Q2, Q3 or Q4 for specific site conditions (defined as a combination of abiotic properties: slope, aspect and lithology), those conditions more readily degradable will show lower percentages for Q1 and Q2. Third, on a basin basis the perturbation agents and regimes have affected the different site conditions in an homogeneous and not biased way.

Based on these assumptions we proceeded to analyse the variability in site conditions for the Chefchaouen basin.

The number of possible combinations for the three site variables: lithology, slope and aspect, considering the different categories defined for each one, generated 246 possible site conditions. To determine if there were any similar pattern in the percentages for Q1, Q2, Q3 and Q4 among different site conditions a cluster analysis was applied to all of them. Terrains with the same site conditions, although may appear in more than one location and in fragments of different size, were summed together. Just one set of values for Q1 through Q4 percentages was assigned per site condition. These values were obtained for the total area present for every site condition.

Five patterns were found significant in the cluster analysis. They are described in table 3 presenting the cluster means (or average from the values for the variables Q1 through Q4 for all the site conditions in each cluster) and their standard deviations respectively.

The five clusters identified by the mean percentage of area covered by each structural type were ordered along a degradation gradient. The order of cluster codes from less to more degraded patterns was 1, 5, 3, 4, and 2 . Those less degraded had higher percentages for Q1 and Q2 (in which the tree overstorey is present) while in the more degraded ones type Q3 was dominant.

The reduced amount of clusters defined facilitated the search for trends in the relationship between site conditions and structural patterns. The relations observed are presented in table 4 . Each cell or square of the table

\begin{tabular}{|l|l|l|l|l|}
\hline CLUSTERS & Q1\% & Q2\% & Q3\% & Q4\% \\
\hline 1 & $92.1 \pm 7.3$ & $4.7 \pm 5.8$ & $2.3 \pm 5.1$ & $0.8 \pm 2.9$ \\
\hline 2 & $15.2 \pm 11.2$ & $8.5 \pm 8.8$ & $74.2 \pm 19.4$ & $2.1 \pm 7.0$ \\
\hline 3 & $22.7 \pm 11.3$ & $71.6 \pm 10.3$ & $4.1 \pm 5.9$ & $1.6 \pm 4.0$ \\
\hline 4 & $38.6 \pm 9.0$ & $39.9 \pm 11.3$ & $18.4 \pm 14.8$ & $2.9 \pm 5.1$ \\
\hline 5 & $63.4 \pm 7.6$ & $28.1 \pm 11.2$ & $7.0 \pm 11.0$ & $1.4 \pm 5.3$ \\
\hline GRAND MEAN & 54.4 & 32.2 & 11.7 & 1.7 \\
\hline
\end{tabular}

Table 3.- Mean values for percentages and Standard Deviations of area covered by the four cork oak formations structural types per cluster group.

\begin{tabular}{|c|c|c|c|c|c|c|c|c|c|c|}
\hline $\mathbf{N}$ & SL1 & SL2 & SL3 & SLA & SL5 & SL6 & SL7 & SL8 & SL9 & SL10 \\
\hline $\mathrm{Ll}$ & B & $B$ & B & B & $\mathrm{B}$ & B & B & + & + & \pm \\
\hline $\mathrm{L2}$ & B & $\mathrm{C}$ & 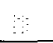 & B & 8 & C & C & \pm & 4 & - \\
\hline L3 & B & B & B & B & C & $\mathrm{C}$ & $\because$ & : & D & - \\
\hline L4 & $\mathrm{B}$ & B & B & 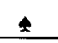 & \pm & 1 & \pm & $\mathrm{B}$ & B & $\perp$ \\
\hline L5 & $\mathbf{E}$ & B & $\therefore$ & 8 & B & B & B & $\mathrm{B}$ & B & 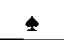 \\
\hline L6 & C & C & 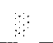 & 8 & & 8 & 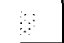 & ע & 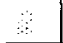 & \pm \\
\hline $\mathbf{E}$ & SL.1 & SL2 & SL3 & SL4 & SL5 & SL6 & SL7 & SL8 & SL9 & SL10 \\
\hline $\mathrm{L1}$ & B & B & 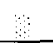 & $\therefore$ & . & 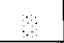 & 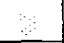 & 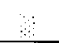 & $\mathrm{B}$ & - \\
\hline $\mathrm{L} 2$ & B & $\therefore$ & $\mathrm{B}$ & $\mathrm{B}$ & $\mathrm{B}$ & $\mathrm{B}$ & C & - & - & - \\
\hline $\mathrm{L3}$ & $\mathrm{C}$ & B & $\mathrm{B}$ & B & B & : & $\mathrm{B}$ & 8 & B & \pm \\
\hline L4 & $\mathrm{C}$ & B & $\because$ & B & $\mathrm{B}$ & B & 1 & 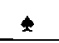 & 1 & - \\
\hline$\llcorner 5$ & $\square$ & C & C & 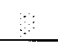 & 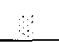 & : & $B$ & B & s & - \\
\hline L6 & B & B & 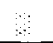 & s & $\mathbf{1}$ & a & $\square$ & 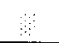 & a & घ \\
\hline $\mathbf{S}$ & SL1 & SL2 & SL3 & SLA & SL5 & SL6 & SL7 & SL8 & SL9 & SL10 \\
\hline L1 & \pm & 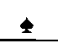 & 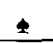 & + & B & 8 & $\mathrm{~B}$ & $\mathbf{E}$ & - & - \\
\hline $\mathrm{L} 2$ & B & $\because$ & B & \pm & \pm &. & B &. & - & - \\
\hline $\mathrm{L} 3$ & $\mathrm{C}$ & B & B & $\mathrm{B}$ & 2 & $s$ & 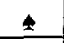 & 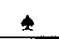 & $\leq$ & $\mathrm{B}$ \\
\hline L4 & C & $\mathrm{B}$ & C & $\mathrm{C}$ & 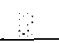 & 8 & B & B & $\square$ & - \\
\hline$\llcorner 5$ & 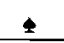 & $\mathrm{C}$ & C & 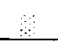 & C & $\mathrm{B}$ & $\mathrm{B}$ & B & B & - \\
\hline L6 & C & C & C & C & C & C & $\mathrm{C}$ & C & * & - \\
\hline $\mathbf{W}$ & SL1 & SL2 & SL3 & SL4 & SL5 & SL6 & SL7 & SL8 & SL9 & SLL10 \\
\hline $\mathrm{L} 1$ & $\perp$ & B & B & $\mathrm{B}$ & $\mathrm{B}$ & $\mathrm{B}$ & $*$ & + & \pm & + \\
\hline $\mathrm{L} 2$ & 1 & B & B & $\therefore$ & 8 & 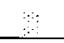 & $\leq$ & 1 & - & -- \\
\hline $\mathrm{L} 3$ & B & $\mathrm{B}$ & B & B & $\mathrm{B}$ & B & $B$ & 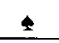 & - & - \\
\hline$\underline{L A}$ & $\mathrm{C}$ & $\mathrm{C}$ & $\mathrm{C}$ & $\therefore$ & $\mathrm{s}$ & $\mathrm{B}$ & B & 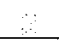 & $\mathrm{C}$ & - \\
\hline L5 & $I$ & I & $\mathrm{B}$ & : & 8 & $\mathrm{~B}$ & B & B & \pm & - \\
\hline L6 & C & C & C & $\because$ & & 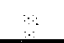 & 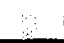 & C & C & C \\
\hline
\end{tabular}

Table 4.- Associacion between cork oak formations structural clusters and site characteristics. The symbols indicate the cluster types. The symbols corresponding to each cluster type are: $\wedge=1, B=5, C=3,=4, \mathbf{m}=2$. They are order from the less to the most degraded. 
represents a different site condition. The table is divided in the four sections. Each one of them has in upper left hand side corner a letter indicating aspect, one of the three site variables considered. All the cells for the first sector are exposed to the north, the following three sectors included aspects to the east, south and west respectively. The ten slope categories considered, define the columns of the table and the six lithologies, the rows of the different sectors. Inside every cell a symbol indicates the pattern shown by the percentages of area of that specific site condition covered by each structural type (Q1, Q2, Q3 and Q4). This is the same as saying that each site condition was assigned the cluster code in which it was included. The symbols were used to make easier the reading of the table. The black square represents the conditions in which around $74 \%$ of their area is covered by Q3 structural type. Therefore, important degradation had ocurred. On the other hand, those cells that present a spade sign indicate that around $92 \%$ of their area is covered by Q1 type forests, hence very well structured.

The trends observed in the structural patterns per site conditions could be summarized as follows:

a. The pattern defined for cluster 5 is the most frequent among different sites, while that for cluster 2 is the less frequent.

b. Those site conditions that show a lower structural disruption are located on slopes oriented to the south. They have the larger number of Q1 dominant patterns as well as the lowest frequencies of site conditions with patterns dominated by Q3 structural types.

c. Sites with better structural types are more frequent in areas with slope above $18 \%$. They are less frequent in lithologies type 5 and 6 . These same two lithologies show a higher accumulation of more degraded structural patterns (cluster codes 2, 4 and 3).

$\mathrm{d}$. The best cork oak forest structure is maintained in sites on northern aspect with lithologies 1 and 4, as well as those oriented to the east and lithology type 4, southern aspect and lithology type 3, and western aspect and lithologies 1 and 3 .

The trends observed in specific site characteristics for table 4 do not indicate which is the weight, in relation to the area covered, that the different site conditions have in the Chefchaouen basin. To solve this problem table 5 indicates which is the extension of each type of site condition with the same frame used in table 4 . The symbols assigned make reference to the area present in the basin for every site condition. The frequency distribution for the total per site condition showed an unimodal structure with a high frequency in the very low sizes (areas smaller than 50 ha.) and with a long tail with one or two areas of very large size (above 500 ha.). The intervals defined to sum- marize this information in table 5 are not homogenous in size to better reflect these tendencies. The hyphen signs in the table indicate those conditions that are not present in the basin. These lacking conditions are centered on slopes above $28 \%$, but more than half of them belong to slopes above $50 \%$. The cells that appear empty indicate that the area they occupy individualy ranges between 1 and 50 hectares. These conditions add up to 2949 ha. what represents a $23.5 \%$ of all the cork oak formations present in the basin. The area included in each of the intervals defined, as well as what they represent in percentage, can be summarized as follows: sites conditions with extension greater than (GT) 50 ha. and less than or equal to (LE) 100 ha.: 2157

\begin{tabular}{|c|c|c|c|c|c|c|c|c|c|c|}
\hline $\mathbf{N}$ & SLI & SL2 & SL3 & SLA & SL5 & SL. 6 & SL7 & SL8 & SLY & SLIO \\
\hline L1 & & & 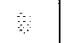 & th & 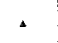 & & $\star$ & & & \\
\hline $\mathrm{L} 2$ & & & $\frac{4}{31}$ & $\frac{\pi}{\pi}$ &. & &. & & & - \\
\hline $\mathrm{L} 3$ & & . & & $\frac{11}{11}$ & it & $\AA$ &. & & & -- \\
\hline $\mathrm{LA}$ & & & & & & & & & & \\
\hline$\llcorner 5$ & & & & & & & & & & \\
\hline L6 & & & & & & & $\frac{n}{\pi}$ &. & & \\
\hline $\mathbf{E}$ & SL1 & SL2 & SL3 & SL $A$ & SL 5 & SL6 & SL7 & SL8 & SL9 & SL10 \\
\hline L1 & & $\frac{\pi}{\pi}$ & I & & $\underline{H}$ & $\triangle$ & tw & & & - \\
\hline $\mathrm{L} 2$ & &. & $\frac{n}{i t}$ & $\sharp$ & 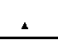 & & 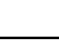 & - & - & - \\
\hline $\mathrm{L} 3$ & & $\frac{\pi}{\pi}$ & 口 & 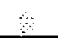 & it. & . & itt & $\Delta$ & & \\
\hline L4 & & & & $\triangle$ & A & & 些 & & & - \\
\hline L5 & & & & & & &. & & & - \\
\hline L6 & & & & & A &. & 8 & $\frac{\pi}{t}$ & $\pi$ & \\
\hline $\mathbf{S}$ & SL1 & SL2 & SL3 & SL4 & SL5 & SL6 & SL 7 & SL8 & SL9 & SL10 \\
\hline $\mathbf{L} 1$ & & & iti. & $\underline{\Downarrow}$ & $\Delta$ & & & & - & - \\
\hline $\mathrm{L} 2$ & & & & & & & & & - & $\ldots$ \\
\hline L3 & & 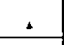 & 齿 & \pm & 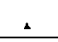 & & & & & \\
\hline I.4 & & & & & & &. & & & - \\
\hline L5 & & & & & & & & & & - \\
\hline $\mathrm{L} 6$ & & & & & & & & & & - \\
\hline $\mathbf{W}$ & SL1 & SL2 & SL3 & SLA & SL5 & SL6 & SL7 & SL8 & SL9 & SL10 \\
\hline L1 & & & the & 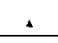 & & & & & & \\
\hline $\mathrm{L} 2$ & th & &. & 4 & & & & & - & - \\
\hline L3 &. & H &. & & & & & & - & - \\
\hline LA & & & & & & & & & & - \\
\hline $\mathrm{L} 5$ & & & & & & & & & & - \\
\hline L6 & & & & & & & & & & \\
\hline
\end{tabular}

Table 5.- Surface occupied by habitat type in the Chaouen basin: (GT=Greater than), (LE=LESS THAN OR EQUAL TO) / GT. 1000 HAS $=\square$; GT 500 and LE 1000 HAS. $=\mathbf{\square}$; GT 300 and LE $500 \mathrm{HAS}$. $=;$ GT 100 and LE $300 \mathrm{HAS} .=+$; GT 50 and LE $100 \mathrm{HAS}=\boldsymbol{\Delta}$; the empty square indicte surface occupied LE 50 Has; not present in the basin $=$ - . 
ha., 17.2\%; GT 100 ha. \& LE 300 has.: 3452 ha. , $27.5 \%$; GT 300 ha. \& LE 500 ha.: 1946 ha. , 15.5\%; GT 500 ha. \& LE 1000 ha.: 626 ha., $5 \%$; GT 1000 ha.: 1416 ha. and $11.3 \%$. There are just 7 site conditions with large areas (GT 300 ha.) and they represent $31 \%$ of the cork oak formations. These areas belong to lithologies 1 and 3 for slope classes 3 and 4 . This is the same as saying that the larger areas of cork oak formations with homogeneous site conditions in the basin show a northern or eastern aspect, have a lithology of colluvial materials (glacis) or cretaceous marls and have slopes between 7 and 15\%. We will call these, group I conditions. These same lithologies and slopes have a high representation in south and west aspects. There is also a conspicuous area with north and east aspect and numidian sandstones (litho6) in higher slopes with values around $28 \%$.We will call these, group 2 conditions.

When these more extended site conditions are checked against table 4 , we see that group 1 presents a pattern of structural types defined by cluster code 5 for northern aspect and southern aspect for lithology 3 . Nevertheless the structural pattern present in easter aspect site in lithology one show a higher degradation with a pattern where Q1 structure just reach a $39 \%$ and Q3 almost a $20 \%$. It is interesting to point out that this same lithology and slope class with a southern aspect presents a very well preserved cork oak formation (cluster code 1) with a dominant $92 \%$ QI structure. On the other hand group 2 conditions show the maximum degradation identified in our patterns with a domminance of up to $74 \%$ in Q3 structural type. This would indicate a complete lost of the tree canopy in conditions that have an important representation in area.

\section{Detailed characterization of selected representative cork oak formations stands:}

As a first approach to the study and quantification of the structure a number of stands where selected previously to the GIS analysis. They were representative of the most common physiognomic types that could be identified in a visual inspection of different Quercus suber formations of the area. The plots selected reflect the remaining cork oak forests, the shrublands derived from them that have lost nearly all the trees for this species, as well as the pine plantations mainly with Pinus pinaster that with a productive intention are introduced in completely cleared or very degraded cork oak forests and shrublands. In the following sections we describe the information obtained as a first approach. A broader and more detailed quantification will be needed in order to have the necessary basis for a rational management of these stands. In first place, we quantify structural characteristics for shrublands (matorrales) or for the shrub layer in the formations that present a tree canopy. In second place, the tree component of the previous stands it are quantified. This section includes an estimation of aboveground biomass for the cork oak tree compartment.

\section{a. Shrub compartment:}

The description for total vegetation cover and for those species that have an interest as a possible fuel source is included in table 6. Besides cover, an indirect indication of the density of shrubs present is given by the number of contacts in 100 meters of line transect. It can be seen that both cork oak forests and matorrals have total cover values above $40 \%$. While pine plantations have a wide range of possible cover values, between $8 \%$ and $80 \%$. When we analyse the cover values for the different species, Erica arborea show the highest values in all the formations. Arbutus unedo, followed by Cistus salvifolius, Cistus crispus and Myrtus communis appear in cork oak forests. Arbutus unedo, Myrtus communis and Cistus salvifolius are not present in most of the pine plantations and matorral sites. Cistus monspeliensis reach the highest values in the matorral stands, while it is almost absent in the rest of stands. Erica arborea appears as the second species in the matorral and in most cases with a short difference in cover (around a 5\%) with Cistus monspeliensis. After Erica arborea, Cistus crispus appears as the third species in importance among those considered.

\section{b. Tree compartment:}

The basic dendrometric tree populations descriptors are used to define both Pinus pinaster and Quercus suber. All this information is included in table 7 . The range of density values for cork oak is included in that for Pinus pinaster. The maximum density values determined for cork oak and pine respectively were 700 and 860 trees/ha. Basal area for cork oak had a minimum of 18.4 $\mathrm{m}^{2} / \mathrm{ha}$. and a maximum of $24.3 \mathrm{~m}^{2} / \mathrm{ha}$. Pinus pinaster presents for all the cases basal area values higher than for any of the cork oak stands studied with a maximum in 34.3 $\mathrm{m} 2 /$ ha.. The most frequent cork oak tree has a d.b.h. between 16 and $22 \mathrm{~cm}$. and heights between $7.4 \mathrm{~m}$. and 11.5 m.. For Pinus pinaster the most common trees have a d.b.h. between 19.5 and $33 \mathrm{~cm}$. and heights from 2.2 to 12.8 meters. Maximum heights attained by cork oak and pine differ in three meters when compared the two stands that appeared more mature.

Once that the basic parameters of the dominant trees have been characterized an estimation of the biomass was completed for the different stands described. The total aboveground biomass estimated as well as the division of it in the different fractions of the tree are important in order to quantify the possible amount of resource obtained from 


\begin{tabular}{|c|c|c|c|c|c|c|c|c|c|c|c|}
\hline \multicolumn{12}{|c|}{$\begin{array}{l}\text { VEGETATION COVER FOR DOMINANT SPECIES IN THE SHRUB LAYER OF QUERCUS SUBER } \\
\text { STANDS OR DERIVED FORMATIONS }\end{array}$} \\
\hline $\begin{array}{l}\text { VEGETATION } \\
\text { FORMATION }\end{array}$ & \multicolumn{4}{|c|}{$\begin{array}{l}\text { CORK OAK } \\
\text { FORESTS }\end{array}$} & \multicolumn{3}{|c|}{$\begin{array}{l}\text { PINE } \\
\text { PLANTATIONS }\end{array}$} & \multicolumn{4}{|c|}{ MATORRAL } \\
\hline PLOT NUMBERS & 20 & 13 & 12 & 10 & 8 & 7 & 5 & 22 & 18 & 17 & 15 \\
\hline $\begin{array}{l}\text { T. VEG. COVER / } \\
\text { CONTACTS } 100 \mathrm{~m} \text {. }\end{array}$ & $\begin{array}{l}97 \\
216\end{array}$ & $\begin{array}{c}66 \\
191\end{array}$ & $\begin{array}{l}70 \\
136\end{array}$ & $\begin{array}{c}41 \\
216\end{array}$ & $\begin{array}{c}8 \\
42\end{array}$ & $\begin{array}{l}22 \\
86\end{array}$ & $\begin{array}{c}80 \\
127\end{array}$ & $\begin{array}{c}77 \\
272\end{array}$ & $\begin{array}{l}43 \\
194\end{array}$ & $\begin{array}{l}115 \\
196\end{array}$ & $\begin{array}{c}89 \\
249\end{array}$ \\
\hline Erica arborea & $\begin{array}{l}49 \\
56\end{array}$ & $\begin{array}{l}30 \\
52\end{array}$ & $\begin{array}{l}15 \\
24\end{array}$ & $\begin{array}{l}10 \\
38\end{array}$ & $\begin{array}{c}7 \\
15\end{array}$ & $\begin{array}{l}0 \\
1\end{array}$ & $\begin{array}{l}28 \\
30\end{array}$ & $\begin{array}{l}20 \\
72\end{array}$ & $\begin{array}{l}10 \\
33\end{array}$ & $\begin{array}{l}0 \\
0\end{array}$ & $\begin{array}{l}25 \\
65\end{array}$ \\
\hline Cistus monspeliensis & $\begin{array}{l}0 \\
0\end{array}$ & $\begin{array}{l}0 \\
0\end{array}$ & $\begin{array}{l}0 \\
1\end{array}$ & $\begin{array}{c}7 \\
21\end{array}$ & $\begin{array}{l}0 \\
0\end{array}$ & $\begin{array}{c}4 \\
13\end{array}$ & $\begin{array}{c}0.3 \\
1\end{array}$ & $\begin{array}{l}35 \\
81\end{array}$ & $\begin{array}{l}15 \\
45\end{array}$ & $\begin{array}{c}81 \\
228\end{array}$ & $\begin{array}{l}29 \\
68\end{array}$ \\
\hline Arbutus unedo & $\begin{array}{l}27 \\
41\end{array}$ & $\begin{array}{l}22 \\
49\end{array}$ & $\begin{array}{l}19 \\
27\end{array}$ & $\begin{array}{l}1 \\
8\end{array}$ & $\begin{array}{l}0 \\
0\end{array}$ & $\begin{array}{l}0 \\
0\end{array}$ & $\begin{array}{l}12 \\
30\end{array}$ & $\begin{array}{l}0 \\
0\end{array}$ & $\begin{array}{l}0 \\
0\end{array}$ & $\begin{array}{l}0 \\
0\end{array}$ & $\begin{array}{l}0 \\
1\end{array}$ \\
\hline Myrtus communis & $\begin{array}{c}3 \\
12 \\
\end{array}$ & $\begin{array}{c}2 \\
11\end{array}$ & $\begin{array}{c}8 \\
18\end{array}$ & $\begin{array}{l}1 \\
2\end{array}$ & $\begin{array}{l}0 \\
0\end{array}$ & $\begin{array}{l}0 \\
0\end{array}$ & $\begin{array}{l}15 \\
15\end{array}$ & $\begin{array}{l}0 \\
0\end{array}$ & $\begin{array}{l}1.5 \\
15\end{array}$ & $\begin{array}{l}0 \\
0\end{array}$ & $\begin{array}{l}0 \\
0\end{array}$ \\
\hline Cistus crispus & $\begin{array}{c}5 \\
26\end{array}$ & $\begin{array}{l}1 \\
8\end{array}$ & $\begin{array}{l}0 \\
0\end{array}$ & $\begin{array}{l}13 \\
71\end{array}$ & $\begin{array}{l}0 \\
1\end{array}$ & $\begin{array}{l}17 \\
25\end{array}$ & $\begin{array}{c}0.7 \\
1\end{array}$ & $\begin{array}{l}17 \\
68\end{array}$ & $\begin{array}{c}6 \\
32\end{array}$ & $\begin{array}{c}0.1 \\
2\end{array}$ & $\begin{array}{l}24 \\
53\end{array}$ \\
\hline Cistus salviifolius & $\begin{array}{c}7 \\
22\end{array}$ & $\begin{array}{c}7 \\
28\end{array}$ & $\begin{array}{l}22 \\
33\end{array}$ & $\begin{array}{c}4 \\
34\end{array}$ & $\begin{array}{l}0 \\
0\end{array}$ & $\begin{array}{l}0 \\
0\end{array}$ & $\begin{array}{l}5 \\
7\end{array}$ & $\begin{array}{c}0.2 \\
5\end{array}$ & $\begin{array}{l}0 \\
0\end{array}$ & $\begin{array}{l}0 \\
0\end{array}$ & $\begin{array}{c}0.8 \\
5\end{array}$ \\
\hline
\end{tabular}

Table 6.- Description of vegetation cover and number of contacts in line transects 100 meters long for plots representative of the typical cork oak forests and derived formations after perturbation and management (pine plantations and matorral). Each cell contains an upper number that indicates cover (\%) and a lower number indicating the contacts. T. VEG. COVER considers all the species together. Values are given for species that are collected as fuel wood by local people.

\begin{tabular}{|c|c|c|c|c|c|c|c|c|c|c|c|}
\hline \multicolumn{12}{|c|}{ DENDROMETRIC CHARACTERIZATION OF STANDS WITH TREE OVERSTOREY } \\
\hline \multirow[t]{2}{*}{$\begin{array}{r}\text { Plot } \\
\#\end{array}$} & \multirow[t]{2}{*}{ Sp. } & \multirow{2}{*}{$\begin{array}{l}\text { Basal } \\
\text { Area } \\
\mathrm{m}^{2} / \mathrm{ha}\end{array}$} & \multirow{2}{*}{$\begin{array}{l}\text { Density } \\
\text { trees/ha }\end{array}$} & \multicolumn{5}{|c|}{$\begin{array}{l}\text { D.B.H. } \\
(\mathrm{cm} .)\end{array}$} & \multicolumn{3}{|c|}{$\begin{array}{l}\text { TREE HEIGHT } \\
(\mathrm{cm} .)\end{array}$} \\
\hline & & & & Min & $\operatorname{Max}$ & Avr & Mod & $\mathrm{N}$ & Max & Mod & $\mathrm{N}$ \\
\hline 20 & Q.s. & 21.3 & 700 & 6 & 35.5 & 18.5 & 16 & 70 & 1120 & 740 & 10 \\
\hline 13 & Q.s. & 18.4 & 580 & 5.5 & 33 & 19 & 19 & 58 & 1479 & 1150 & 29 \\
\hline 12 & Q.s. & 24.3 & 690 & 10 & 31 & 20.5 & 16 & 69 & 1680 & 860 & 32 \\
\hline 10 & Q.s. & 18.8 & 470 & 14 & 35 & 22 & 22 & 47 & 1120 & 610 & 41 \\
\hline 8 & P.p. & 34.3 & 730 & 14 & 32 & 24 & 25.5 & 73 & 1390 & 1280 & 39 \\
\hline 7 & P.p. & 26.5 & 300 & 22.5 & 41.5 & 33 & 33 & 30 & 1950 & 1580 & 30 \\
\hline 5 & P.p. & 25.7 & 860 & 6 & 33.5 & 18.5 & 19.5 & 86 & 1240 & 220 & 6 \\
\hline
\end{tabular}

Table 7.- Dendrometric description of the tree compartment in cork oak or derived forest rerpesentative stands. Sp. = species: Q.s. = Quercus suber; P.p. = Pinus pinaster D.B.H. = diameter at breast height; Min = minimum; Max = maximum; Avr = average; Mod = mode; $\mathrm{N}=$ number of trees measured. 


\begin{tabular}{|c|c|c|c|c|c|c|c|c|c|}
\hline \multicolumn{10}{|c|}{$\begin{array}{c}\text { ABOVEGROUND BIOMASS FOR QUERCUS SUBER STANDS AND } \\
\text { PERCENTAGES ALLOCATED TO DIFFERENT FRACTIONS }\end{array}$} \\
\hline PLOT \# & B.A. & T.A.B. & SUM.B. & PBTBS & PBB & PBPB & PBSB & PBBK & PBL \\
\hline 12 & 24.3 & 134.9 & 172.62 & 78.15 & 35.11 & 23.11 & 22.30 & 18.59 & 0.88 \\
\hline 20 & 21.3 & 118.6 & 160.73 & 73.79 & 34.16 & 24.39 & 22.58 & 17.98 & 0.89 \\
\hline 10 & 18.8 & 107.7 & 130.79 & 82.35 & 34.33 & 25.61 & 21.03 & 18.20 & 0.83 \\
\hline 13 & 18.4 & 100.7 & 134.92 & 74.64 & 35.21 & 22.38 & 22.98 & 18.53 & 0.90 \\
\hline
\end{tabular}

Table 8.- Aboveground biomass for Quercus suber stands and percentages allocated to each tree fraction. B.A. = basal area $\left(\mathrm{m}^{31}\right.$; T.A.B. $=\mathrm{total}$ aboveground biomass obtained from the sum of the biomass estimated for the different fractions independently; PBTBS = Percentage of SUM.B. that represents T.A.B.; $\mathrm{PBB}=$ percentage of biomass in bole (not including bark); $\mathrm{PBPB}=$ percentage of biomass in primary branches; $\mathrm{PBSB}=$ percentage of biomass in secondary branches; $\mathrm{PBBK}=$ percentage of biomass in bark; $\mathrm{PBL}=$ percentage of biomass in leaves.

different extraction types. The range of biomass observed went from 100.7 to $135 \mathrm{Tm} / \mathrm{ha}$. The amount accumulated for secondary branches would range between 23.1 and $30.1 \mathrm{Tm} / \mathrm{ha}$. The biomass in leaves could range between 0.91 and $1.19 \mathrm{Tm} / \mathrm{ha}$. The normal way in which comsumption of both wood and fodder occurs makes necessary to consider individual trees. In fact, cork oak forests degradation initiates in the continuous cutting of the top of trees as fuel wood and forrage. The most frequent trees available would range between 16 and $22 \mathrm{~cm}$. d.b.h.. These trees would have individual dry weights for total, secondary branches and leaves respectively of: 85,48 and $1.9 \mathrm{~kg}$. and 204,59 and $2.3 \mathrm{Kg}$. The largest d.b.h. measured was 35.5 and the dry weights for this tree for the same fractions would be 780,79 and $3.1 \mathrm{~kg}$.

If we consider the whole basin, an estimate for the amount of cork oak tree dry matter present could be obtained from the percentage of area covered with Q1 and Q2 structural types. We assigned the highest value of biomass estimated, to the area covered with Q1 type structure and the lowest value to the area with Q2 type structure. The total cork oak tree dry matter present in the basin was $1.332 \times 10^{6} \mathrm{Tm}$.

\section{DISCUSSION}

1. Environmental heterogeneity:

Lithology, slope and aspect were selected as the best environmental descriptor, for they act as synthetic variables and they were easy to obtain given the limitation in available information on the area. The different categories defined for these three characteristics had not homogeneous representation in the Chefchaouen basin. The combination of them allowed to typify the dominant site conditions. The graphic representation (Tables $4 \& 5$ ) allows to establish a quantitative method of comparation with other basins in the Rif. On the other hand, this approach does not consider the spatial pattern that would be fundamental on a landscape ecology perspective. But to understand the meaning of the possible mosaics of these site conditions, on a landscape basis, it is necessary, before, to know which are their individual influence on vegetation structure.

\section{Structural patterns in cork oak formations:}

The structure of the cork oak formations is a result of many different perturbations interacting and with a wide variety of temporal regimes. The most important perturbations affecting the cork oak forests in the region are fire, biomass extraction as fuelwood or fodder, overgrazing and tillage. At a scale of the whole Mediterranean basin GRENON \& BATISSE (1988) pointed out that from all the forests systems of the world, those in the Mediterranean Sea perimeter and in continental China are the ones with a higher degradation by human action. The combined action of tillage, overgrazing and use of wood as a fuel and construction material have caused incalculable damages. The conclusions to their analyses on the future of the Mediterranean basin estimate that till the year 2025 for all the Mediterranean countries together, wildfires could destroy 10 to 12 millions hectares of forests, tillage between 5 and 6 millions has., overgrazing between 2.5 and 3 millions has. and tree cutting for fuelwood between 0.5 and 1 millions has. Grenon \& Batisse, also remark that some of the countries in the southern (Morocco) and in the eastern (Turkey) side of the Mediterranean basin have just partially satisfied their energy needs and provoke a very important pressure that in combination with overgrazing result in the main cause of degradation of these forests.

The environmental heterogeneity observed in the basin can be summarized as: sites with marls (Litho3 type) 
with a broad slope range between $3 \%$ and $35 \%$ on east oriented terrains constrainning its maximum slope on other aspects. Northern aspect followed by southern and western represent the progression. Glacis (Lithol) present a similar trend for slope though its minimum limit is one class higher. The range of slopes covered for each aspect follows the same progression as for litho3. Numidians sandstones (Litho6) is dominant on eastern aspect for slopes between $15 \%$ and a $50 \%$. It is also conspicuous on northern aspects with slopes from $20 \%$ to $35 \%$.

\section{Relationship Environment-Structure:}

The descriptive approach used to show the relationships between certain sites conditions and the structural pattern that dominated does not identify the causes that lead to that situation. If the assumptions stated in the methodology section are true, then those conditions more degraded would be more sensible to perturbation. The solution to this uncertainty will need further studies. However, the data presented would allow to define which site conditions presented a more degraded status. If attention would be placed first on environmental structure diversity the stands to protect would be those belonging to cluster type 2 and with low spatial representation. Nevertheless, there is a direct relation between the spatial area covered and its weight in the control of the functioning of a certain system. The site conditions that occupy areas larger than 50 hectares and present a cluster type 2 (this means that just 15.2\% \pm 11.2 is covered Q1 structure) should be considered preferentially to avoid further degradation. The site conditions included in this later group were: areas with numidian sandstones in slopes between $15 \%$ and $28 \%$ and eastern aspect, as well as sites with the same lithology but oriented to the north and slopes from $28 \%$ to $35 \%$

The functional implications of the heterogeneity described depends clearly on the size of the organisms or scale of the processes that we might be interested in studying as well as in how significant the differences between these site conditions defined are in relation to the structure of the cork oak formations.

\section{Trends in shrub compartment:}

The percentage in cover observed show some trends that would be interesting to evaluate. The almost complete disappearance of Arbutus unedo in the matorrales (mainly Q3 shrublands) while it is the second species in importance in the cork oak forests. We believe this drastic change is related to the type of management that burnt cork oak forests suffer after fire goes through. This process allowed and controlled by the forest authorities permits the uprooting of the lignotubers of Erica arborea, Arbutus unedo, Myrtus communis and other less represented species, as well as, the complete clear cut of the remaining aboveground biomass for Quercus suber trees that with most of the larger size shrub stems are transformed in charcoal on site. Myrtus communis shows a similar trend, while Erica arborea remains but with lower cover values. The much easier establishment capacity of Erica allows that a large number of small size lignotubers of this species remain in the ground after the process fire-charcoal production is completed. We consider this would be the cause of this difference. Once uprooted, the possibilities that both Arbutus, and Myrtus could get established are severely reduced. With fire recurrence the cork oak lignotubers die and there is a simplification in the species composition of the shrub layer. The lost of the tree layer represents a threshold of irreversibility (ARONSON et al. 1993) that once crossed has no real possibility of recovery given the type of forestry that can be seen in the area probably due to limited funding. Therefore the control of the shrub layer should be done as a preventive measure against wildfires in those areas that still keep a good tree canopy.

\section{Trends in tree compartment:}

MONTOYA, J.M. (1984) emphasized the need for forests typification from a sylvicultural point of view to better adapt management processes to the type of stands and to the environment of an specific area. He pointed out that the ecological and silvicultural knowledge for the different types of cork oak forests seems to be the best way to reach the previous goal. ELENA et al.(1984) on the needs to reach an appropriate management for the "Dehesa" systems in southwestern Spain pointed out to the urgent need for information on the tree components and on the territory. Its goal would be the search for a more integrated land-use planning not just centered on urbanizing areas. CARITAT et al. (1991) summarized the structural characteristics for six cork oak forests stands in Gerona (northeast Spain) and showed that the density values determined ranged from 475 to 1024 trees per hectare (tr/ha.). The lowest value in Chefchaouen was $470 \mathrm{tr} / \mathrm{ha}$. but the values for the remaining plots were included in the range observed for Gerona. Four of these stations had similar ranges for d.b.h. but Fitor was the most similar one.

When comparing the d.b.h. observed for our cork oak forests stands it was interesting to observed that given their size classes almost all the trees characterized were outside the lower limit defined by MONTOYA (1986) for d.b.h. classes to be included in a dendrometric survey. This advised lower limit is set at 30 centimeters of d.b.h. This same limit was also used by MONTERO et al. (1991). Of course, both of these papers consider as a priority goal the optimization of cork production. With this goal in mind, 
and considering the dendrometric characteristics of our stands, it would be interesting to check if thinning would be an advisable procedure. Nevertheless, plot number 10 , for example has almost the same density as the lowest value given by CARITAT et al. (1991) for the site named Cartellá. We consider that in our case it would be necessary to determine the amount of lignotubers in relation to stems density. This would improve the selection of stems to cut down, trying to maintain those whose lignotubers presented a higher vigor.

Data for basal area from CARITAT et al. (1991) showed values between 14 and 58 square meters per hectare $\left(\mathrm{m}^{2} / \mathrm{ha}\right.$.) that include the values determined for the stands in Chefchaouen, although below the mean values. The most typical values for different $Q u e r c u s$ species from California extracted from BOLSINGER (1987) suggested that similar values around $22.9\left(\mathrm{~m}^{2} / \mathrm{ha}\right.$.) are common for Quercus chrysolepis, Quercus garryana, Quercus kelloggii, and Quercus agrifolia.

Biomass determination obtained for cork oak trees ranged in our sites between 100.7 and 135 tons per hectare (Tm/ha.). For the two stations described by CARITAT et al. (1992) Fitor with $134 \mathrm{Tm} / \mathrm{ha}$. is the one that seems closer. The Biomass for St. Hilari. Was $328 \mathrm{Tm} / \mathrm{ha}$. The values obtained for Chefchaouen plots would have lower values of biomass. Two aspects should be considered the amount of biomass included in the shrub layer that in most sites will be important given the high cover observed and the fact that most of these stands result from resprouting and we have no information on whether they could be considered mature stands. When compared with other species like Pinus halepensis, it is interesting to observe, as it was shown in PASTOR-LOPEZ et al. (1995a) that mature stands in France in subhumid conditions reach values of up to $161.4 \mathrm{Tm} / \mathrm{ha}$. It is clear that pine plantations that are common in the basin include: young stands with densities of 860 trees per hectare, below the mean value used for Pinus halepensis afforestation in Spain (PASTOR-LOPEZ, 1995) that is around 1200 trees per hectare. The determined basal area for the stands is higher than for the cork oak stands what could be considered as sufficient reason for conversion of degraded cork oak forests to plantations. Although this is a possibility, evaluating other impacts on the ecosystem are necessary mainly in fire-prone ecosystems. Considering the maximum heights reached by these stands and an approximate age of 35 years, these stands would be included in the high quality classes identified by BELGHAZI et al. (1994). MONTERO et al. (1991) quantified the possible biomass extractable from a Pinus pinaster stand in the center of Spain by thinning. All these management options would have to be considered in the search for sustainable systems.
6. Implications on cork oak forests management:

GRENON \& BATISSE (1988) pointed out that fuel wood productivity in the mediterranean natural forests ranged between 0.8 cubic meters per ha. and year $\left(\mathrm{m}^{3} /\right.$ ha.yr.) for dense hardwoods and $0.1 \mathrm{~m}^{3} / \mathrm{ha}$.yr. for the matorral formations. If we consider the Chefchaouen basin cork oak formations and assume that Q1 structural type had the maximum value $0.8 \mathrm{~m}^{3} / \mathrm{ha}$. $y \mathrm{r}$; the $\mathrm{Q} 2$ type have an intermediate value $0.45 \mathrm{~m}^{3} / \mathrm{ha}$.yr. and the Q3 \& Q4 have the minimum value suggested $0.1 \mathrm{~m}^{3} / \mathrm{ha}$.yr. The annual production in relation to the area present in the Chefchaouen basin would be respectively: 5330.6 cubic meters per year $\left(\mathrm{m}^{3} / \mathrm{yr}\right.$.); $1939 \mathrm{~m}^{3} / \mathrm{yr}$; and $158 \mathrm{~m}^{3} / \mathrm{yr}$. This would add up to $7427.5 \mathrm{~m}^{3} / \mathrm{yr}$. GRENON \& BATISSE (1988) also stated that the fuel wood needs are estimated between 0.5 and 1 cubic meter per person and year for the rural people (and even more in some areas from the Magreb or Turkey). If this is applied to the above mentioned value the cork oak formations in the Chefchaouen basin could sustain an energy demand for a population between 7427 and 14854 persons. The productivity will need to be better determined in order to verify the previous estimate, but if the population of Chefchaouen, just one of the cities in the area is more than 40,000 citizens. It seems that the actual exploitation policy of biomass extraction is clearly not sustainable and is reducing the extension of the cork oak forests. GRENON \& BATISSE (1988) indicate that it is an interesting solution the plantations of trees as fuelwood or forage trees in perimeters around areas as a soil conservation, but these methods are not well developed yet.

It is clear that the management of these formations must consider fire as an important perturbation agent MONTOYA (1982) indicates that the fire is present in many areas of cork oak forests and in some way their presence depends on the fire. This author noticed that if an area is protected against fire other competitive species may arrive to outcompete the cork oak eliminating them; in other cases fungi attacks destroy them. He also suggested alternative treatments as shrub clearing and tree thinning in case there was an active fire prevention.

MONTOYA \& MONTERO (1984) found no significative difference in cork production in response to a series of treatments that combined shrub clearing with tillage or fertilization and with both of them. This trend was observed in five stations located in a wide region in the southwest of Spain with stands in the provinces of Cáceres, Badajoz, Huelva, Sevilla and Cadiz. Nevertheless the impact of certain management practices has been identified by MADEIRA \& RIBEIRO (1995) as more important on the changes that soils may undergo than those caused by the respective leaf litter type. This conclusion was rea- 
ched after comparing the effects of Quercus suber, Pinus pinaster and Eucalyptus globulus forest stands in Portugal after a ten-year period of observations.

As MASSON et al. (1994) indicated cork oak forest in northwestern mediterranean are commonly degraded as a result of abandoned exploitations, shrub overgrowth and repeated fires. These causes can be also observed in moroccan cork oak forests. Repeated fires coupled with strong postfire extractions, for fuel consumption, of Quercus suber aboveground biomass and lignotubers from the main sprouting shrubs, can be considered the perturbation with a higher impact and effects on the sustainability of these forest. Despite the negative effect associated with shrub understory development, most cork oak forests in Chefchaouen are protected by the forest authorities against shrub clearing. MASSON et al. (1994) emphasizes the positive effect of shrub clearing and the positive effect of animal herds that control the shrub sprouts with a positive effect to prevent wildfires. The tested and significative results from this study were: shoot elongation was between $28 \%$ and $14 \%$ greater than the control, for stands were shrubs had been cleared and pastured. In relation to radial growth the results were not homogeneous, a positive and significative increase was observed in the italian stands but not in the french and spanish ones. The effect on nutrient uptake were non significative for nitrogen but for phosphorous they were significative specially in plots sowed with leguminous. The improvement caused by the shrub clearing on the water status has positive consequences on production. The control of ligneous sprouts by range is not sufficient for fire prevention if it is done with herds that are not enclosed. Herds of cows, goats and horses with a range pressure from 2 to $4 \mathrm{UGB} / \mathrm{Ha}$ and in rotation among different sites allow a sufficient shrub control compatible with fire prevention. The negative effects that this type of treatment might have on the cork oak regeneration as argued by foresters was also tested. The results indicated that although there was a clear reduction in the regeneration density, the stands that had been cleared still kept up to 1500 trees per hectare. An individual protection of the young trees was suggested as a good solution to make compatible the regeneration capacity of the cork oak as well as the benefits of the silvopastoral management mentioned.

In relation to the extrapolation of these results to other areas the authors state that it is possible based on the fact that the geographical effect was not strong enough to hide the differences due to treatments. The management criteria for cork oak forests must favour a high overstory and reducing the understory shrub layer below 4 meters in height. An intermediate tree canopy cover of 20 to $30 \%$ is considered as a good point to allow the shrub regrowth control by animals at the same time that a herbaceous layer can reach a sufficient production. To allow regeneration simultaneous to a shrub clearing and range utilization treatment the possibilities are: 1) protection of young shoots during their first years. 2) allowing growth of a high number of shoots thinning them when they have reached a certain diameter.

The consequences of different silvicultural and range treatments on cork oak forest in sample plots in France, Italy and Spain were tested by MASSON et al. (1994). Treatments included shrub clearing alone or in combination with range by different species as well as sowing of leguminous plants. After considerable shrub reduction they observed that an herbaceous vegetation of low quality appears with a production of 0.5 to 1 tons of dry matter per hectare and year. If range productive species were introduced (mainly Trifolium subterraneum and Dactylis glomerata) an herbaceous layer of better quality got established with a production ranging between $I$ and 3 tons of dry matter per hectare and year. MASSON (1992) pointed out that this increase in herbaceous layer production was not the only benefit, there was also a $\mathrm{N}$-fixation by these leguminous species of up to $50 \mathrm{~kg} / \mathrm{ha} . \mathrm{yr}$.

It was frequently observed that shepherds in the Chefchaouen basin prune complete crowns of certain cork oak trees as a fodder and wood source. The area were these phenomena were observed was the transition between areas that retained sparse tree canopies and lands that had lost completely their trees and presented important erosion processes. The maximum leaf biomass obtainable from cork oak trees pruning would give between 0.91 and 1.19 $\mathrm{Tm} / \mathrm{ha}$. As indicated in the results, this is the leaf biomass estimated for the range of sites described in the present study. It seems clear that an appropriate protection of the tree compartment is needed and that at least similar fodder production could be obtained from an herbaceous layer obtained or created from shrub conversion. The main difference would be that continuing cork oak trees pruning provokes a continuous reduction of both the density and extension of cork oak forest in the basin, while the establishment of a well structured herbaceous layer generates a sustainable system.

ELENA et al.(1984) pointed out the need for integration between the biological and socioeconomic agents in order to look for solutions to the "Dehesa" ecosystems. Their proposal of the model "productive prunning versus root out" is a good example on this direction. It searches for solutions to the problem of Quercus ilex deforestation caused by the demand of holm oak charcoal that is provoking an important reduction in density of this species and the destruction of the "Dehesa".

The role that pine afforestations play in the degraded cork oak forests has not been studied but it is an impor- 
tant topic, in dealing with the question of what it is the best management option for the matorral areas once Quercus suber has disappeared? We expect to deal with some of these questions in future studies.

Acknowledgements.- We thank Mohammed Ater, Luis Miguel Español, Mohamed Kadiri and Francisco Jose Perez Martinez for field work that allowed to get some of the information used in the discussion. Jose Antonio Pina helped in the field recognition of the lithological types. This work was indirectly supported by EU. MEDCAMPUS program (MC256 \& MB256).

\section{References:}

ARONSON, J.; LE FLOC'H, E.; FLORET, C.; OVALLE, C. \& PONTANIER, R. (1993). Restauration and rehabilitation of degraded ecosystems in arid and semiarid regions. A view from the south. Restoration Ecology 1:8-17.

BELGHAZI, B.; ROMANE, F. (1994) Productivité du Pin maritime (Pinus pinaster Sol. var.magh.) en peuplements artificiels dans le Nord du Maroc. Forêt méditerranéenne. t.XV, nº octobre:391396.

BENABID, A. (1982). Etude phytoécologique, biogéographique et dynamique des associations et séries sylvatiques du Rif occidental (Maroc). Thèse de Doctorat, Fac. Sc. Tech. St. Jérome, Univ. d'AixMarseille, $199 \mathrm{p}$

BENABID, A. (1989). Ecologie,conservation et restauration des subéraies. C.R. Session de formation continue sur le liège, Juin 1985. Doc. E.N.F.I. Salé, 1-16.

BOLSINGER, CH. L. (1987). Major findings of a Statewide Resource Assessment in California. in T.R. Plumb \& N. H. Pillsbury, Multiple-Use Management of California's Harwood Resources. U.S.D.A. Forest Service, General Technical Report PSW-100. pp.:291-297.

BOUKIL, A. (1989). La dégradation des groupements forestiers et préforestiers dans le Rif centro-occidental et ses conséquences socioéconomiques.In Colloque "Montagnes rifaines: homme et espace", Tétouan, 33p.

CARITAT, A.; MOLINAS, M.L.; OLIVA, M. (1991). Estructura y crecimiento del alcornocal gerundense. Studia Oecologica, VIII,(159170)

CARITAT, A.; OLIVA, M.; MOLINAS, M.(1992). Distribución de la biomasa en dos parcelas de alcornocal. Scientia gerundensis, 18 131-142.

DI CASTRI, F.(1981). Mediterranean-type shrublands of the World. Ch. 1; in Ecosystems of the World. vol. 11. Ed. Di Castri et al.Elsevier Pub. Amsterdam. 643 p

DIXON, W.J. (1983). B.M.D.P. Statistical Software. University of California Press, Berkeley.

ELENA, M. \& BORRALLO, J.M. (1984) Coste de producción de carbón de encina: el modelo "poda productiva vs. arranque" y su contribución a una política sectorial. Anales I.N.I.A./Serie Economía y Sociología Agraria. n8:9-32.

GRENON, M. \& BATISSE, M. (1988). El Plan Azul: El futuro de la
Cuenca Mediterranea. Monografías de la Secretaría General de Medio Ambiente. PNUMA-CAR/PB. Ministerio de Obras Públicas y Transportes. Madrid pp.496.

LE HOUEROU, H.N.(1981). Impact of Man and his animals on Mediterranean Vegetation. Ch. 25; in Ecosystems of the World. 11 Elsevier Pub.

LUBCHENCO, J. et al. (1991). The Sustainable Biosphere Initiative: an ecological research agenda. Ecology 72:371-412

MADEIRA, M. ;RIBEIRO, C. (1995). Influence of leaf litter type on the chemical evolution of a soil parent material (sandstone) Biogeochemistry 29:43-58.

MASSON, PH. (1992). Systèmes d'élevage et remise en valeur des subéraies des zones nord méditerranéennes. Scientia gerundensis, 18: $113-119$

MASSON, PH.; ANTHELME, B.; ARRO, B.; BERTONI, G.; ROBERT, B.; MOLINAS, M.L.; CARITAT, A.; VILAR, L.; POLO, L.; DOMINGUEZ-PLANELLA, A.; SUNYER, D.; ABOS, L.; CAMPOS, M.; PINTUS, A.; RUIU, P.A.; PAMPIRO, F.; PRODON, R. (1994). Influence des traitements sylvicoles de la subéraie sur la production et la cqualité du liège et sur la protection de la forêt contre les incendies. Rapport de Synthèse. Contrat MA2B CT 91 0019(DTEE). p.86.

MONTERO, G.; SAN MIGUEL, A.; ALIA, R. (J991). Estructura y producción de los alcornocales (Quercus suber L.) del Sur de España. Investigación Agraria. Sistemas y Recursos Forestales. I.N.I.A. $\mathrm{n}^{\circ} 0:$ : 69-74.

MONTERO, G.; GOMEZ, J.A.; ORTEGA, C. (1991). Estimación de la productividad aérea en una repoblación de Pinus pinaster Ait. en el Centro de España. Investigación Agraria. Sistemas y Recursos Forestales. I.N.1.A. no0:191-202

MONTOYA, J.M. (1982). Selvicultura Mediterranea: Consideraciones ecológico-selvícolas sobre el alcornocal y su repoblación. Boletín de la Estación Central de Ecología. vol.11-n $21: 3-10$.

MONTOYA, J.M. (1984). Tipilicación forestal de los bosques españoles. Los alcornocales (Quercts suber) (L.). Boletín de la Estación Central de Ecología. Vol.13,25:1-8.

MONTOYA, J.M. (1986) Ecología, silvopascicultura y ordenación de los alcornocales. (Una síntesis práctica). Boletín de la Estación Central de Ecología. vol. 15, n²9:3-10.

NAHAL, 1. (1981). The Mediterranean climate from a biological view point. In DI CASTRI, F., D.W. GOODALL, R.L. SPECHT (Eds.) Mediterranean-type shrublands. Ecosystems of the World. vol. 11 Ch. 3, pp. 63-86. Elsevier Scientific Publishing Company. Amsterdam.

PASTOR-LOPEZ, A. (1995). Repoblaciones forestales con Pinus halepensis en la provincia de Alicante. Evaluación ecológica del método de revegetación habitual en la cuenca mediterránea española pp.81-120; en: Restauración de la cubierta vegetal en ecosistemas mediterráneos. In PASTOR-LOPEZ, A. \& SEVA-ROMAN, E (Eds.). Instituto de Cultura Juan Gil-Albert. Diputación Provincial de Alicante. 212 p.

PASTOR - LOPEZ, A. \& MARTIN, J. (1995). Ecuaciones de biomasa para Pinus halepensis en repoblaciones de la provincia de Alicante. Studia Oecologica XII (79-88). 